Article

\title{
On the Political Decision of Audit Market Regulation: Empirical Evidence of Audit Firm Tenure and Maximum Durations within the European Union
}

\author{
Markus Widmann ${ }^{1}$, Florian Follert ${ }^{2, *(\mathbb{D})}$ and Matthias Wolz ${ }^{1}$ (D) \\ 1 Faculty of Business Administration, Accounting \& Auditing, University Trier, Universitätsring 15, \\ 54296 Trier, Germany; widmann@uni-trier.de (M.W.); wolz@uni-trier.de (M.W.) \\ 2 Faculty of Management, Seeburg Castle University, Seeburgstraße 8, 5201 Seekirchen, Austria \\ * Correspondence: florian.follert@uni-seeburg.at
}

check for updates

Citation: Widmann, Markus, Florian Follert, and Matthias Wolz. 2021. On the Political Decision of Audit Market Regulation: Empirical Evidence of Audit Firm Tenure and Maximum Durations within the European Union. Economies 9: 79. https:// doi.org/10.3390/economies9020079

Academic Editors: Ralf Fendel and Andrea Appolloni

Received: 12 January 2021

Accepted: 12 May 2021

Published: 20 May 2021

Publisher's Note: MDPI stays neutral with regard to jurisdictional claims in published maps and institutional affiliations.

Copyright: (c) 2021 by the authors. Licensee MDPI, Basel, Switzerland. This article is an open access article distributed under the terms and conditions of the Creative Commons Attribution (CC BY) license (https:// creativecommons.org/licenses/by/ $4.0 /)$.

\begin{abstract}
After almost every economic crisis and corporate scandal, political actors announce the need for stricter regulatory measures for financial markets and companies, in an attempt to appease their voters and defend their political agenda. Regarding the latest international financial crisis, the EU responded, among other things, with comprehensive regulation of the European audit market. In the context of auditor rotation, after 17 June 2016, the duration of audit engagements should not exceed a maximum of 10 years. In this paper, we therefore investigate whether there is empirical evidence behind the 10-year threshold—or is it simply arbitrary? Our aim is to evaluate the audit market reform by the European Union (EU) (Regulation (EU) No 537/2014 and Directive, $2014 / 56 / \mathrm{EU})$ related to the objective of improving the quality of audits. Therefore, our article addresses the most crucial element of this reform, the implementation of a mandatory audit firm rotation for public interest entities (Regulation (EU) No 537/2014, Article 17). Based on a unique dataset of 11,834 firm observations from all listed companies within the EU between 2008 and 2017, we provide for the first time a discussion basis for the assessment of audit market interventions by the EU. Hence, we compare the new maximum durations with average audit tenure in the particular member states. Even where we present only descriptive results, our results at least indicate that the "magic number" 10 (years) could be more the result of a political process-i.e., a consent between the European institutions-rather than evidence based. Therefore, our findings shall serve as a first starting point in the discussion of a vast and interdisciplinary research field.
\end{abstract}

Keywords: audit market; Public Choice; regulation; auditor tenure; rotation; EU; decision-making

\section{Introduction}

The Regulation of the (European) audit market has a long tradition (e.g., Evans and Honold 2007; Humphrey et al. 2011; Naumann 2014), even before the Fourth Directive in 1978 (78/660/EEC) was implemented. Over the past few decades, the regulation of this important profession has repeatedly been a political issue. The starting points for these measures were, on the one hand, several harmonization efforts within European commercial and corporate law and, on the other hand, various scandals, and economic crises (e.g., in Germany, the real estate entrepreneur Schneider (see e.g., Herzig and Watrin 1995) or Philipp Holzmann AG, (see e.g., Wolz 2004). The regulation of the European audit market was not isolated from developments in the United States, where various measures to regulate the audit market were taken as a pilot for other countries, particularly after the "Enron-scandal" and the resulting collapse of the audit firm Arthur Andersen, within the framework of the resulting "Sarbanes-Oxley Act" (SOX, Coates 2007).

The issue of the regulation of auditors is of particular interest in view of the latest scandal involving the payment service provider, Wirecard AG (Zeit Online 2020). According to recent media reports, the role of the auditing company EY is also being scrutinized in this 
context. The German Finance Minister, Olaf Scholz, for instance, felt the need to consider stronger financial regulation and oversight of the auditing profession. In addition to the possibility of a more distinct separation between the auditing and consulting businesses (possibly the introduction of pure audit firms), Scholz specifically questions the recently introduced maximum term for the auditing of annual financial statements (Zeit Online 2020). He does not object to the introduction of obligatory change of auditor after a certain period of time, but rather strongly favors shorter rotation periods than currently exist.

Since 2007, the financial industry, the so-called "real economy" and governments have been struggling with the aftermath of the last financial crisis (e.g., Barth et al. 2010; Rudolph 2010). Although there were multiple causes, government action in the form of more lenient monetary policy in combination with fair value accounting is seen as a major culprit (e.g., Huerta de Soto 2009; Hering et al. 2010; Brösel et al. 2012; on the problems of fair value accounting see further, e.g., Biondi 2011; Braun 2019). The European institutions have concluded that, in addition to close monitoring of the financial sector (e.g., Kaserer 2010; Davies 2015), the auditing market must also undergo fundamental changes. As part of the reform process of the recent global financial and economic crisis, further and stricter regulatory measures were taken. The purpose of these fundamental market reforms was intended to regain public confidence in the audit profession after several scandals and crises (e.g., Daniels and Booker 2011; Tan and Ho 2016).

Our analysis needs to be based on real-world circumstances, and in the real world, government interventions play an increasingly important role (e.g., Kurrild-Klitgaard 2005). However, it is also well known in the economic literature that government intervention does not solve problems, but on the contrary can exacerbate problems (e.g., Mises 1926, 1957, 1998). If we take the example of central bank control of interest rates or fractional reserve banking, it is precisely these interventions that lead to renewed crises. Ludwig von Mises described this early on as an intervention spiral, so that a dynamic process toward a planned economy is set in motion (see further on this problem, e.g., Bagus 2011, 2013, 2015).

Regarding these events, the European Union introduced a mandatory (external) auditor rotation for public interested entities (PIE) (e.g., Tan and Ho 2016), which are defined as entities which are of significant public interest by virtue of their fields of activity, their size, or the number of their employees, or which have a large number of shareholders due to their corporate forms (in the following: "EU audit market reform"). Apart from banks and insurance companies, these include above all listed corporations within the EU (e.g., Widmann and Wolz 2019). The primary objective of the EU audit market reform is the improvement of both the quality of the audit as well as the significance of the auditor's reporting. The EU believes that the quality of the audit can be increased if the independence of the statutory auditor is sustainably strengthened.

At this stage, we first refer to the comprehensive study by Willekens et al. (2019), which already describes various effects of EU audit market reform. In this study, the effects on costs, concentration, and competition on the audit market are mainly presented. However, the aspect of audit firm tenure was not considered. Second, we refer to another study by Audit Audit Analytics (2020) that had already published these audit firm tenure data from PIE within the EU. However, their presented dataset covers recently published financial statement data without academic discussion. Furthermore, and due to the up-todate mentioned dataset, the effects of the EU audit market reform already applied to these results. Within our paper we will compare audit firm tenure data collected from financial statements of listed entities within the EU before and after the introduction of the EU audit market reform in 2014 and 2016 and discuss in detail the decision by politicians to establish maximum durations.

Against the background of a classical liberal position and the idea of free competition as a fundamental freedom of the European Union, the central definition of maximum terms must be discussed critically. In particular, the member states differ in terms of their legal, economic, and cultural conditions. According to Brooks et al. (2017), the optimal audit firm tenure should depend on the legal regime of a country and especially on investor 
protection. They point out the implication that longer auditor tenure would be favorable for countries with a strong system of investor protection. Given this, it would be interesting to conduct further research and compare auditor tenure in each European country with strictness of company law. Hayek (1945) emphasizes the decentralization of regulations in general, including decentralized distribution of knowledge within a society. Especially, decentralized regulation of the profession would be the most preferable. Nevertheless, it is also the task of science to take existing conditions as given and evaluate them. This is the central aim of the present paper. To accomplish this, we used empirical data to analyze the structure of the currently valid rotation system for auditors across the EU against the background of recent demands for a shorter maximum term of mandate.

In deciding to establish a maximum duration for audit engagements, an adequate tenure needs to be defined. Bear in mind that the EU intended to stimulate the audit market by making the decision to establish an audit firm rotation system. This action will only lead to significant changes in the market and a reduction of audit firm tenure when the average of the tenure of audit engagements at that time exceeds the agreed-upon maximum duration. Our paper does not discuss audit firm rotation as a measure to stimulate the market-our objective is much more based on the following research questions (RQ):

RQ 1: Is there a connection between the political decision by the EU to set a specific point value as maximum duration and empirical results?

RQ 2: What effect has Regulation (EU) No. 537/2014 had, and continues to have, when and since it was published?

The remainder of this paper is structured as follows: In Section 2 we outline the theoretical and political background, in particular the main goals of the EU reform of the audit market and their potential consequences from an economic point of view. In Section 3 of the paper, we present empirical evidence. We evaluate the established maximum duration set by the European Union based on a unique dataset considering all available listed companies within the EU with respect to their auditor tenure over time. In the following Section 4 the newly installed maximum durations, by referring to the origins and the different perspectives of the participating entities within the EU at that time, will be discussed from a politico-economic perspective. Section 5 provides an outlook on further research.

Overall, we would like to contribute to a broader discussion concerning the regulation of the European audit market that could integrate the perspective of Public Choice to provide new insights about political interventionism in the market. Based on our extensive dataset we ask the provocative question whether 10 years are more are "proven or popular"? With respect to our data, the findings at least give a first indication of the latter.

\section{Background}

\subsection{Audit Firm Rotation and Agency Theory}

A generally accepted approach to explain the need for an external audit is the agency relationship between the management (agent) of a corporation and its shareholders (principals) (e.g., Ross 1973; Jensen and Meckling 1976), which is based on the separation of ownership and control (Berle and Means 1968). The fundamental agency-theoretical approach is based on the fact that the monetary compensation of management depends in part on the company's annual profit. However, the management as the agent can influence financial accounting through earnings management. Therefore, this results in an asymmetrical distribution of information between principal and agent (e.g., Pratt and Zeckhauser 1985), which leads to discretionary potentials and finally a moral hazard problem (e.g., Holmström 1979). In the absence of their own expertise, the shareholders incur high control costs, which they try to reduce by entrusting an external auditor with the task of auditing the correctness of financial accounting (Ewert 1990). However, it is obvious that the appointment of an external auditor creates new agencies and new conflicts of interest (Ewert 1990). New problems of asymmetrical distribution of information then arise through the auditor as an agent before the mandate is issued (problem of adverse 
selection through hidden characteristics) or after the mandate is issued (moral hazard through hidden action and hold-up through hidden intention) (concerning auditing see, e.g., Ewert 1990; Marten 1994). The auditor's performance depends largely on his or her individual level of effort, if we simply assume that only capable auditors act in the market.

Baiman (1979, p. 29) emphasizes this agency-problem as follows: "If the owner hires an auditor to make sure that the manager is not cheating him, how is the owner assured that the auditor is not also cheating him by not delivering the agreed upon level of auditing services? This is an important issue since auditing services are not observable by the owner". In analogy to research within the field of new institutional economics, relevant audit research examines different measures to reduce the different agency conflicts. The basic assumption is that an average individual can be influenced by changing incentives within their subjective decision field towards more or less desirable actions (e.g., McKenzie and Tullock 1978; Opp 1999; Kirchgässner 2013; Emrich and Follert 2019).

One approach to reduce the conflicts of interest discussed in the literature is the legal obligation of auditor rotation, which is intended to prevent a coalition of interests between management and the auditor at the expense of the owners, which could result from a longterm contract (on auditor independence, see DeAngelo 1981). Since Chung and Lindsay (1988), auditor tenure has become an important topic within international audit research, for example, concerning a determinant for audit pricing (e.g., Simon and Francis 1988; Tanyi and Litt 2017; Ettredge et al. 2018; Widmann et al. 2021) or the question of auditor's independence (e.g., Marten 1994).

From a theoretical point of view, the auditor rotation requirement emphasizes two main objectives (e.g., Tan and Ho 2016):

(1) To increase auditor's independence (on auditor independence, see DeAngelo 1981;

Daniels and Booker 2011; Hossain 2013);

(2) To improve competitiveness within the audit market.

(Ad 1) Regulators follow an economic argument (see e.g., Carcello and Nagy 2004, p. 58; Carey and Simnett 2006, p. 656). Within international literature the relationship between auditor and client is a well-known topic, especially concerning risks that result from a close connection. The increasing duration of the contractual relationship between the auditor and the company to be audited creates a growing dependency, which is intended to have a negative impact on the auditor's judgement and its independence and is ultimately reflected in reduced audit quality, which has already been revealed, for example, in the "Enron scandal". However, the auditing profession argues that the audit's quality is lowest in the early years of the engagement.

(Ad 2) The current market for audits is dominated by the Big Four audit firms and can be characterized as an oligopoly with only few suppliers and many demands. The high market concentration in the supply side of the audit market, especially in Germany, is a well-known topic in the literature (e.g., Bigus and Zimmermann 2008; Velte and Stiglbauer 2012; Tan and Ho 2016; Neurohr et al. 2019). These findings apply especially to the auditing of PIE, as the Big Four audit firms can realize economies of scale here and the market cannot be served by smaller audit firms. The regulation of the PIE sub-market is therefore seen as important because there should be a greater welfare effect if there were any inefficiency (Tan and Ho 2016).

Like any human decision, political action must be guided by a consideration of the expected costs and benefits. From an economic perspective, a legal restriction of the freedom of contract between auditor and auditee would be justified only if there is a negative correlation between duration and audit quality. For the economic assessment of a mandatory rotation, a differentiated consideration is necessary, and we will build on Herzig and Watrin (1995) in the following:

We start from the assumption that there is a rotation that emerges without a fixed mandatory period. It is generally known that a first-time audit involves high implementa- 
tion costs for the auditor. If the budget is tight due to legal deadlines, the intensity of the audit and consequently the audit quality may be compromised. Learning effects could arise on the part of the auditor over time, but these are limited by the obligation to rotate, so that it can ultimately occur that a company can avoid an intensive audit over a longer period of time (Herzig and Watrin 1995). In such a situation, the management has a strategic advantage, as it can terminate the contract without difficulty, so that a new auditor would in turn have high transaction costs. This results in a hold up problem, so that the effect on the relationship between management and owner that was originally intended with the installation of an auditor is not achieved.

We assume that there is a rotation with a fixed mandatory period. Such a mandatory period could have a problematic effect on the contractual relationship in two ways. On the part of the audit firm, there is a moral hazard for the client that the audit fees will increase after the first period (Herzig and Watrin 1995). Setting the fee for the entire duration of the mandate also appears impracticable, as many cost components are subject to external influences that appear difficult to calculate for a longer period (on the determinants of audit fees, see Widmann et al. 2021). Moreover, it is obvious that a legal rotation with a fixed mandatory duration creates another moral hazard problem regarding the efforts of the auditor. If the auditor does not fit the expectations, the owners as principal do not have the legal authority to withdraw from the contractual relationship (Herzig and Watrin 1995).

From an agency-theoretical point of view, it seems to be evident that a rotationregardless of case (1) or (2) - evokes different problems. As already mentioned, any intervention in a competitive market is accompanied by economic welfare effects. Especially from a classical liberal perspective, a forced maximum duration can be viewed critically. In particular, the question arises of how any supervisory authority can define an adequate point value for a maximum duration. First, it is questionable whether such an optimum can be determined a priori by political actors or whether the duration of a mandate is not rather a market outcome that has to be "discovered" first (see Hayek 1969). From a theoretical perspective, this is clear, since the dispersion of relevant knowledge cannot allow for a planning solution (Hayek 1945). However, if we already have political intervention in the market and freedom of contract, then this intervention must at least be comprehensible and it is important to consider the agency problems mentioned by Herzig and Watrin (1995) when designing the rotation system. Therefore, we plea at least for an ex-post evaluation of the political measures. Thus, if we try to approximate the political decision on audit market regulation concerning auditor rotations within the EU, this can hardly be done without empirical analysis, which is the goal in this paper. However, if there is no empirical evidence for the necessity to cap auditor tenure, what (political) reasons could there be in installing it, nevertheless?

\subsection{Auditor Rotation within the EU}

Considerations in introducing a rotation requirement were already discussed by the European political parties more than twenty years ago. The first indications within the EU date back to 1996, when the independence of those auditors who audited the same client over many years was first questioned. At that time, however, the EU Commission already pointed out possible efficiency and quality disadvantages that could arise in connection with external rotation. The fact that internal rotation should primarily affect companies that are of public interest was discussed by the EU Commission on 15 December 2000, but this was merely a proposal to the member states. The next steps towards introducing a rotation system were initiated by the EU Commission in 2004. However, the final version of the Audit Directive from 2006 only contained regulations on internal rotation and thus was a more moderate implementation than initially intended. External rotation was rejected again because the EU was convinced that it would have a negative impact on audit quality and that there would be more disadvantages than advantages. Consequently, and following SOX requirements by the US, a seven-year internal rotation system was introduced at that time. The client's audit partner in charge of the audit was only allowed to carry out 
the audit of the client again after a cooling-off period of 24 months (Art. 42 II Directive, 2006/43/EG).

On 13 October 2010, the European Commission (EU Commission) published the Green Paper on "Audit Policy: Lessons from the crisis". That paper was based on 38 questions linked to the audit profession and had the objective of stimulating the market. With question number 18, the EU Commission reopened the ongoing debate on a possible mandatory audit firm rotation after a certain maximum duration of the audit mandate. The initiators argued that regularly internal audit partner rotation would still be incompatible with desirable standards of independence (European Commission 2010).

The period of consultation was open for nearly two months, and it closed on 8 December 2010. Attendees consisted of relevant representatives from practice, politics, and science. Finally, over 600 comments were submitted, in which the EU Green Paper, and above all, a possible audit firm rotation was controversially discussed. All of these responses were published on the website of the European Union. Böcking et al. (2011) evaluated all feedback and concluded that the majority (71\%) of the participants opposed the introduction of an external rotation requirement. Therefore, the authors found no indication for the need for any reform regarding a potential audit firm rotation. In contrast to this evaluation by Böcking et al. (2011), the EU Commission claimed that they had received "very strong support from investors" for the introduction of a mandatory audit firm rotation (see PCAOB 2012, pp. 209-10, statement by Ms. Berger from EU Commission speaking at $\mathrm{PCAOB}$ ).

Article 17 of Regulation (EU) No. 537/2014 finally introduced external audit firm rotation for all public interest entities in the European Union. Even though any regulation by the European Union is, in principle, directly applicable law in all member states, it was only able to establish the framework of rotation rules. So, it was stated that the tenure of the audit engagement should not exceed the maximum duration of 10 years. However, member states were allowed to implement the following rules in their national law as explicitly suggested by the European legislator:

(1) by setting a maximum duration of less than 10 years,

(2) by extending the initial maximum duration up to

- 20 years, when a public tendering process is conducted after the expiry or,

- 24 years, when a joint audit is performed after the expiry.

Thereafter, a new duration of the cooling-off period was set as four years during which the statutory auditor may not audit the former client. This period can be extended by explicit decisions based on national laws of the member states.

In addition to the question of whether external rotation should be introduced at all, the EU discussed widely the necessary follow-up consideration of the number of years of audit activity after which audit firm rotation should apply. Since it was explained that the reform measures were to be understood as a legal framework and required mandatory implementation or concretization by the national legislators, the resulting national regulations will be referred to in the following. The following summary presents the implementation of the EU reforms by the respective member states for the companies affected in the EU. The relevant information was taken from the website of the European Contact Group (ECG). The ECG conducted a survey of the respective member states using a standardized questionnaire. The results of the survey thus serve as a data source, which is independently summarized and processed in Table 1. 
Table 1. Overview of maximum durations within the EU (see e.g., Accountancy Europe 2020; Widmann and Wolz 2020, p. 137).

\begin{tabular}{|c|c|c|c|c|}
\hline Member State & Maximum Duration before Extending Options & Extending Option? & Joint Audit Option? & Maximum Duration Including Extensions \\
\hline Austria & 10 & No & No & 10 \\
\hline Belgium & 9 & Yes & Yes & 24 \\
\hline Bulgaria & 7 & No & No & 7 \\
\hline Cyprus & 10 & Yes & Yes & 24 \\
\hline Czech Republic & 10 & Yes & No & 20 \\
\hline Denmark & 10 & Yes & No & 20 \\
\hline Estonia & 10 & Yes & No & 20 \\
\hline France & 6 & Yes & No & 20 \\
\hline Germany & 10 & Yes & Yes & 24 \\
\hline Greece & 10 & No & No & 10 \\
\hline Hungary & 10 & No & No & 10 \\
\hline Iceland & 10 & Yes & No & 20 \\
\hline Ireland & 10 & No & No & 10 \\
\hline Italy & 9 & No & No & 9 \\
\hline Latvia & 10 & Yes & No & 20 \\
\hline Lithuania & 10 & No & No & 10 \\
\hline Malta & 10 & Yes & No & 20 \\
\hline Netherlands & 10 & No & No & 10 \\
\hline Poland & 5 & No & No & 5 \\
\hline Portugal & 9 & No & No & 9 \\
\hline Romania & 10 & Yes & No & 20 \\
\hline Slovakia & 10 & Yes & Yes & 24 \\
\hline Slovenia & 10 & Yes & No & 20 \\
\hline Spain & 10 & No & Yes & 14 \\
\hline Sweden & 10 & Yes & Yes & 24 \\
\hline
\end{tabular}


Table 1. Cont.

Additional information

\begin{tabular}{|c|c|c|}
\hline \multicolumn{3}{|r|}{ Additional information } \\
\hline * & Croatia & 7 years for banks. \\
\hline * & Hungary & 8 years for banks. \\
\hline * & Germany & No extension options for banks and insurances. \\
\hline$* *$ & Belgium & Possible extension for public tender process limited to 9 years; possible extension for joint audit option is 15 years. \\
\hline ** & Croatia & No extension options for banks. \\
\hline ** & Sweden & No extension options for banks and insurances; possible extension for joint audit option limited to 4 years. \\
\hline$* * *$ & France & Mandatory joint audit for consolidated accounts. \\
\hline$* * *$ & Spain & Possible extension for joint audit option limited to 4 years. \\
\hline
\end{tabular}


As we can see in Table 1, the maximum duration is from 5 to 24 years with an average of 16.88 years.

Companies affected by regulation 537/2014 must have the status of a "public interest entity (PIE)". Directive 2014/56/EU—which was introduced after Regulation 537/2014redefined this term. According to Art. 2 No. 13 of that directive, all capital market-oriented enterprises, credit institutions and insurance companies are classified as PIE. In addition, member states could include further companies as PIEs if they are of considerable public importance due to their activity, size, or number of employees. Within the European Union Area, Accountancy Europe identified 19,068 public interest entities that will be affected by the EU reforms as of November 2017 (see Widmann and Wolz 2019).

\section{Analysis}

\subsection{Political Decision and Prior Empirical Results}

To give an answer to RQ 1 we performed a literature review on audit firm tenure and audit quality. Previous archival data study results related to auditor tenure mainly refer to jurisdictions that do not have a mandatory audit firm rotation system in place. However, they investigate the effect of auditor tenure on audit quality. If, in that context, it should turn out that audit quality decreases over time, it would be interesting to find out from which point in time onward this is the case.

Johnson et al. (2002) divided all audit engagements into three sections (short, mediumand long-term engagements). They found out that short audit firm tenure (2-3 years) is usually associated with lower audit quality. The study further compared medium auditfirm tenure (4-8 years) and long audit-firm tenure engagements ( 9 years and more). The results indicate that long audit-firm tenure is not associated with a decline in audit quality as measured by discretionary accruals. Since quality losses tend to occur within the first two to three years, a mandatory audit-firm rotation every ten years (or even more frequently) would lead to an overall reduction in audit quality, since initial audits (with lower quality) would occur more frequently.

Myers et al. (2003) investigated the influence of audit firm tenure on earnings quality, as measured by different proxies. They found out that both discretionary accruals and current accruals decrease as auditor tenure increases. However, they also noted that the magnitude of income increasing accruals as well as income decreasing accruals lessens with the increasing length of the relationship. Although they conclude that their study did not provide evidence on whether a mandatory audit firm rotation system should be implemented, they did not find any evidence for a potential limitation of ten years (or any other figure).

Chen et al. (2008) examined the influence of audit firm and audit partner tenure on audit quality of Taiwanese companies as measured by performance adjusted discretionary accruals. They found out that audit quality significantly improved with audit firm tenure as absolute discretionary accruals decrease significantly over time. In the end, the results of this study argue against the rotation rules introduced by the EU, because the poor-quality audit years, with a basic rotation period of ten years, too often repeat themselves, and an improvement in the audit quality only occurs from the sixth year onwards, and even more so from the tenth year onwards. However, the question remains open as to whether the audit quality improves consistently in a linear fashion after the tenth year or whether it diminishes at some point.

Jackson et al. (2008) examined the audit market in Australia. The authors conclude that the length of the auditor-client relationship has neither an economic nor a statistically significant impact on audit quality when measured by discretionary accruals. In addition, they found out that audit quality increases with audit firm tenure when measured by an alternate proxy such as the propensity to issue a going-concern opinion. Therefore, they finally conclude that a mandatory audit firm rotation system would not improve audit quality. 
Davis et al. (2009) evaluated the implementation of SOX in the US in terms of auditor tenure and its effect on audit quality, measured by discretionary accruals, to meet or exceed earnings forecasts. The results indicate that audit firm tenure is associated with an increase in discretionary accruals in the pre-SOX period (1988-2001), but not in the periods following SOX (2002-2006).

Al-Thuneibat et al. (2011) examined the effect of the length of the auditor-client relationship and the size of the audit firm on audit quality in Jordan. In the overall result, the authors demonstrate that the length of the mandate period adversely affects audit quality. The longer the audit relationship, the higher the level of DPAs, and consequently, the lower the audit quality. To ensure high audit quality, the authors argue that rules that establish a regular rotation of auditors are essential. Otherwise, the auditors would compromise their objectivity and independence. A long term, which has a significant negative impact on audit quality, is indicated here as nine years.

Quick and Wiemann (2011) found out several effects concerning the German audit market. At first, their results indicated an increase in audit quality over time-especially when an initial period of three years of the engagement has passed. The authors argue that this period could be seen as an induction or training phase for the auditor to become more familiar with his clients. The authors also divide the length of audit engagements into three sub-areas: short terms of up to three years, medium terms of up to seven years and long audit terms from the seventh year onwards. Basically, they conclude that audit quality constantly improves with the duration of the mandate. Particularly, they point out that audit quality in the initial phase of the first three years shows clear deficits compared to the following four years. From the seventh year onwards, their results did not indicate further significant changes in the audit quality. Accordingly, the level remains quite stable from a medium-length term of office of seven years. However, Quick and Wiemann (2011) state that their results are only valid for the regulation system at that time (2005-2007) which had no mandatory audit firm rotation system in effect. Nevertheless, their important study does not indicate arguments to implement such a system, nor to limit the maximum duration by ten years.

The study by Kwon et al. (2014) examines the impact of auditor rotation on audit quality and on audit fees in South Korea. Two different time windows are considered. The first is the impact of the duration of the mandate on audit quality before the introduction of auditor reform in South Korea, i.e., from 2000 to 2005, and the second is the impact of the mandate duration on audit quality after the introduction of auditor reform, i.e., from 2006 to 2009. Overall, the authors found that the introduction of audit rotation had not significantly changed audit quality. The quality did not significantly improve or deteriorate either in initial audits resulting from the audit reform or in subsequent years. Compared also with the quality of the audit of long mandate durations before the reform, there is no deviation. In fact, in both observation periods, it is better in those companies that change auditors voluntarily and at short intervals. However, since the change of auditor due to the reform has no perceivable positive effect on the quality of the audit, the authors ultimately reject a mandatory regular change of auditor.

Reguera-Alvarado et al. (2019) suggest a U-shaped relation between audit firm tenure and earnings management. For that reason, they added two tenure variables (tenure + tenure $^{2}$ ) into their regression model. Their results of different audit market (US, UK, Japan, Italy, France, and Spain) can confirm the suggested association at a low significance level ( $p$-value $<0.1)$. However, they state that the lowest point value concerning audit firm tenure is at seven years. Taking this result into consideration, a mandatory audit firm rotation would make sense at this point in time and not, as decided by the EU, only after ten years.

Taking all these results of the above-mentioned empirical studies into consideration, there is no clear evidence that audit firm rotation has any positive influence on audit quality. Consequently, there is no indication of an optimal audit tenure. It must be mentioned that prior literature concerning the influence of the duration of an audit relationship or the 
effect of market interventions by the legislator on audit's quality are mainly available in international jurisdictions outside the EU (see, e.g., Ghosh and Moon 2005; Knechel and Vanstraelen 2007; Boone et al. 2008; Chen et al. 2008; Lim and Tan 2010; Baatwah 2016; Kim et al. 2019). Nevertheless, it would be surprising to find different results in the EU. In any case, it is evident that the political decision to set 10 years as the point value of the basic term cannot be justified by previous studies (especially of international audit markets).

\subsection{Effect of Regulation (EU) No. 537/2014}

\subsubsection{Data Information}

Our data set concerning the European audit tenure regulation is based on the following considerations: we decided not to include data from companies from the United Kingdom as they were not any longer part of the European Union. We also excluded data for comparability reasons from France, as that country is the only member state that has a mandatory joint audit requirement for all consolidated entities. We also did not include banks, insurance and other companies operating in the Financial Services field as for these sectors some member states decided to define specific maximum durations.

Apart from this, and based on a query in the Eikon database of Thomson Reuters, we collected all the remaining listed companies within the EU from the included member states that were listed on any stock market as per 30 June 2019.

For all these identified companies, we hand-collected information about auditor tenure and auditor's opinion from 2008 to 2017. That window allowed us to evaluate auditor tenure before and after discussion, decision, and implementation of audit firm rotation. Companies without recoverable data had to be excluded.

Comparing with the number of PIE respectively listed entities in the member states as stated by Accountancy Europe (see Accountancy Europe 2017) we achieve a coverage of about $36 \%$ of all listed companies (see Table 2).

Table 2. Coverage ratio.

\begin{tabular}{|c|c|c|c|c|}
\hline Country & Number of PIEs & Number of Listed Entities & Entities Included in Our Study & Coverage Ratio (\%) \\
\hline Austria & 239 & 84 & 22 & 26.19 \\
\hline Belgium & 342 & 152 & 54 & 35.53 \\
\hline Bulgaria & 569 & 321 & 25 & 7.79 \\
\hline Croatia & 500 & 127 & 13 & 10.24 \\
\hline Cyprus & 118 & 76 & 22 & 28.95 \\
\hline Czech Republic & 150 & 74 & 6 & 8.11 \\
\hline Denmark & 360 & 200 & 103 & 51.50 \\
\hline Estonia & 30 & 13 & 16 & 123.08 \\
\hline Finland & 469 & 136 & 122 & 89.71 \\
\hline France & 1796 & 483 & 0 & 0.00 \\
\hline Germany & 1150 & 800 & 268 & 33.50 \\
\hline Greece & 325 & 233 & 44 & 18.88 \\
\hline Hungary & 195 & 44 & 11 & 25.00 \\
\hline Iceland & 175 & 18 & 5 & 27.78 \\
\hline Ireland & 1200 & 54 & 28 & 51.85 \\
\hline Italy & 917 & 233 & 199 & 85.41 \\
\hline Latvia & 87 & 42 & 21 & 50.00 \\
\hline Lithuania & 150 & 20 & 13 & 70.00 \\
\hline Luxembourg & 583 & 180 & 17 & 9.44 \\
\hline Malta & 91 & 43 & 0 & 0.00 \\
\hline Netherlands & 725 & 125 & 105 & 84.00 \\
\hline Poland & 2000 & 450 & 150 & 33.33 \\
\hline Portugal & 1250 & 54 & 30 & 55.56 \\
\hline Romania & 1000 & 90 & 22 & 24.44 \\
\hline Slovakia & 172 & 73 & 5 & 6.85 \\
\hline Slovenia & 70 & 45 & 12 & 26.67 \\
\hline Spain & 1507 & 188 & 90 & 47.87 \\
\hline Sweden & 621 & 350 & 281 & 80.29 \\
\hline EU in total & 16,546 & 4645 & 1684 & 36.25 \\
\hline
\end{tabular}


In total we collected from 1896 different entities 11,834 firm year observations that are presented country-by-country and year-by-year in Table 3. This makes our data set unique in several respects: We provide the maximum coverage ratio possible per EU member state as well as the maximum coverage of EU member states in the non-financial sector.

Table 3. Number of companies considered per member state.

\begin{tabular}{|c|c|c|c|c|c|c|c|c|c|c|}
\hline \multirow{2}{*}{ Country } & \multicolumn{10}{|c|}{ Periods } \\
\hline & 2008 & 2009 & 2010 & 2011 & 2012 & 2013 & 2014 & 2015 & 2016 & 2017 \\
\hline Austria & 10 & 10 & 10 & 12 & 12 & 15 & 15 & 17 & 19 & 22 \\
\hline Belgium & 26 & 29 & 32 & 32 & 34 & 35 & 37 & 42 & 48 & 54 \\
\hline Bulgaria & 3 & 4 & 4 & 6 & 9 & 10 & 12 & 14 & 16 & 25 \\
\hline Croatia & 1 & 3 & 5 & 7 & 8 & 8 & 8 & 10 & 10 & 13 \\
\hline Cyprus & 16 & 16 & 17 & 17 & 20 & 20 & 20 & 21 & 21 & 22 \\
\hline Czech Republic & 2 & 2 & 2 & 3 & 4 & 4 & 5 & 6 & 6 & 6 \\
\hline Denmark & 52 & 57 & 60 & 68 & 74 & 80 & 91 & 96 & 96 & 103 \\
\hline Estonia & 11 & 12 & 12 & 14 & 15 & 15 & 16 & 16 & 16 & 16 \\
\hline Finland & 62 & 63 & 73 & 77 & 84 & 95 & 104 & 110 & 117 & 122 \\
\hline France & 0 & 0 & 0 & 0 & 0 & 0 & 0 & 0 & 0 & 0 \\
\hline Germany & 133 & 149 & 167 & 182 & 197 & 213 & 223 & 235 & 249 & 268 \\
\hline Greece & 21 & 22 & 26 & 28 & 31 & 31 & 34 & 39 & 39 & 44 \\
\hline Hungary & 5 & 5 & 6 & 7 & 7 & 7 & 7 & 7 & 8 & 11 \\
\hline Iceland & 0 & 0 & 0 & 0 & 0 & 1 & 1 & 4 & 5 & 5 \\
\hline Ireland & 12 & 13 & 14 & 15 & 15 & 17 & 18 & 21 & 25 & 28 \\
\hline Italy & 131 & 136 & 153 & 160 & 173 & 178 & 180 & 186 & 191 & 199 \\
\hline Latvia & 4 & 7 & 8 & 9 & 9 & 9 & 17 & 17 & 17 & 21 \\
\hline Lithuania & 3 & 4 & 5 & 5 & 7 & 8 & 8 & 10 & 10 & 13 \\
\hline Luxembourg & 9 & 10 & 11 & 13 & 13 & 14 & 15 & 15 & 15 & 17 \\
\hline Malta & 0 & 0 & 0 & 0 & 0 & 0 & 0 & 0 & 0 & 0 \\
\hline Netherlands & 38 & 44 & 47 & 50 & 53 & 57 & 78 & 92 & 102 & 105 \\
\hline Poland & 17 & 34 & 44 & 56 & 68 & 85 & 104 & 119 & 133 & 150 \\
\hline Portugal & 13 & 13 & 15 & 17 & 17 & 18 & 22 & 24 & 25 & 30 \\
\hline Romania & 6 & 8 & 8 & 8 & 9 & 10 & 12 & 15 & 21 & 22 \\
\hline Slovakia & 1 & 3 & 3 & 3 & 4 & 5 & 5 & 5 & 5 & 5 \\
\hline Slovenia & 1 & 4 & 4 & 4 & 9 & 11 & 11 & 11 & 11 & 12 \\
\hline Spain & 30 & 33 & 36 & 43 & 48 & 57 & 61 & 68 & 76 & 90 \\
\hline Sweden & 142 & 147 & 158 & 170 & 190 & 209 & 227 & 248 & 263 & 281 \\
\hline Total EU & 749 & 828 & 920 & 1006 & 1110 & 1212 & 1331 & 1448 & 1544 & 1684 \\
\hline
\end{tabular}

Following other studies (Myers et al. 2003; Ghosh and Moon 2005; Reguera-Alvarado et al. 2019), we calculated audit firm tenure as the consecutive number of years that the client has retained the respective audit firm. Since 2016, the auditor's opinion on financial statements includes a notice on the duration of the engagement. Given a long-term relationship where the initial appointment was before 2008, it was easy to fill in the relevant information about auditor tenure as per date by back calculation. For all cases where the first-time appointment of the auditor was within our observation period (2008-2017), we started a backward search by a hand-collection of all publicly available financial statements from the websites of the listed company.

\subsubsection{Aggregated Results}

Table 4 provides descriptive information about our data set regarding audit firm tenure over the years with a focus on financial year 2014 when Regulation (EU) No. 537/2014 was agreed. As we can see there is a minimum in each period of 1 -which means that there are audit firm changes in each period. The range of audit firm tenure is from 1 to a maximum of up to 91 years in the financial year 2017. 
Table 4. Descriptive statistics of audit firm tenure over time.

\begin{tabular}{cccccccc}
\hline Period & $\begin{array}{c}\text { Average Audit } \\
\text { Firm Tenure }\end{array}$ & Std.-Dev. & Min. & $\begin{array}{c}\text { 1st } \\
\text { Quartile }\end{array}$ & $\begin{array}{c}\text { 2nd } \\
\text { Quartile }\end{array}$ & $\begin{array}{c}\text { 3rd } \\
\text { Quartile }\end{array}$ & Max. \\
\hline 2008 & 8.14 & 10.92 & 1 & 2 & 5 & 11 & 82 \\
2009 & 8.33 & 10.77 & 1 & 3 & 5 & 12 & 83 \\
2010 & 8.41 & 10.64 & 1 & 3 & 5 & 12 & 84 \\
2011 & 8.55 & 10.56 & 1 & 3 & 6 & 12 & 85 \\
2012 & 8.58 & 10.51 & 1 & 3 & 6 & 12 & 86 \\
2013 & 8.61 & 10.46 & 1 & 3 & 6 & 12 & 87 \\
2014 & 8.67 & 10.41 & 1 & 3 & 6 & 12 & 88 \\
2015 & 8.56 & 10.32 & 1 & 3 & 6 & 12 & 89 \\
2016 & 8.58 & 10.35 & 1 & 3 & 6 & 11 & 90 \\
2017 & 8.55 & 10.23 & 1 & 3 & 5 & 11 & 91 \\
\hline
\end{tabular}

The average audit firm tenure within the EU for all periods under review is between 8 to 9 years with a slight increase over the years up to the-probably all time-peak in 2014 of 8.67 years. When the EU Green paper was issued in 2010 and the discussion about limiting the maximum duration came up once again, we further notice that there was an increase in auditor tenure before (2008-2010) as anticipated by the politicians (see Figure 1). It is only with the final adoption of the regulation that a decline in auditor tenure can be observed (2014-2015). This decline since the date of publication seems to have continued since the reform finally came into effect (2016-2017). We further notice a decrease in median audit firm tenure from 6 years to 5 years in 2017 which may be explained by the change of particularly long-standing audit mandate relationships.

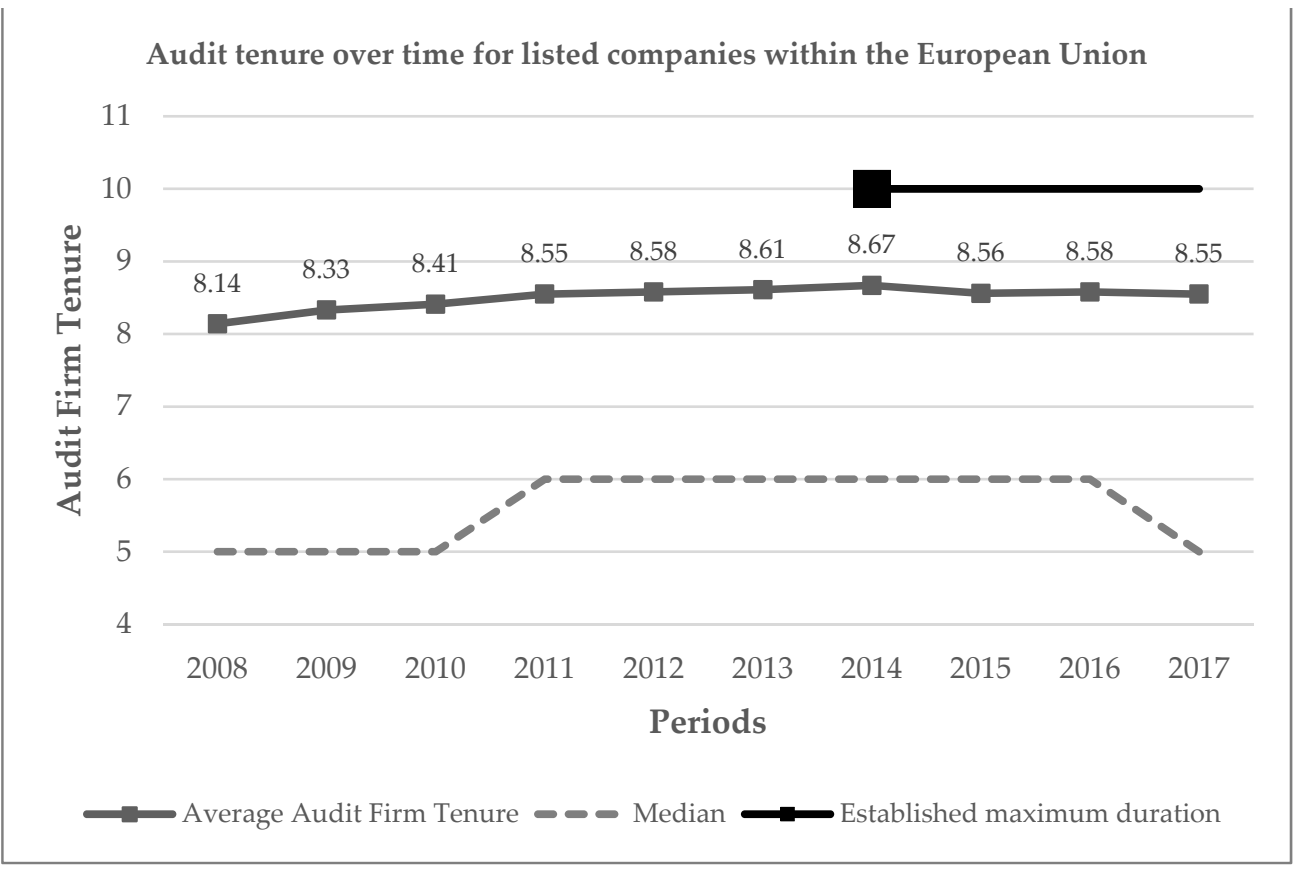

Figure 1. Audit Firm tenure over time.

Figure 2 also shows that the point value of ten years as a maximum for audit duration before potential extension options by the member states is above the respective average audit firm tenure in all periods. However, there is a standard-deviation which is, in all periods, between 10 to 11 years explaining the wide range of audit firm tenure. The standard deviation is quite constant over time, fluctuating between 10.92 (in period 2008) and 10.23 years (in period 2017), whereby it decreases steadily. The minimum value of audit firm tenure in each period is 1 , which means that there is a change of auditor in each period. The analysis of the quartile figures shows that $25 \%$ of all EU companies 
considered have a mandate of 2 years (in 2008) or 3 years (in 2009-2017), the median is between 5-6 years and the 3rd quartile ranks at 11 and 12 years. The respective maximum audit firm tenure is from Germany with the audit of Rheinmetall AG that was performed by PWC for 91 years in 2017. Consequently, the distribution of audit firm tenure in the financial year 2014 (as well as for the other periods) is shown on the left, as we can see in Figure 2.

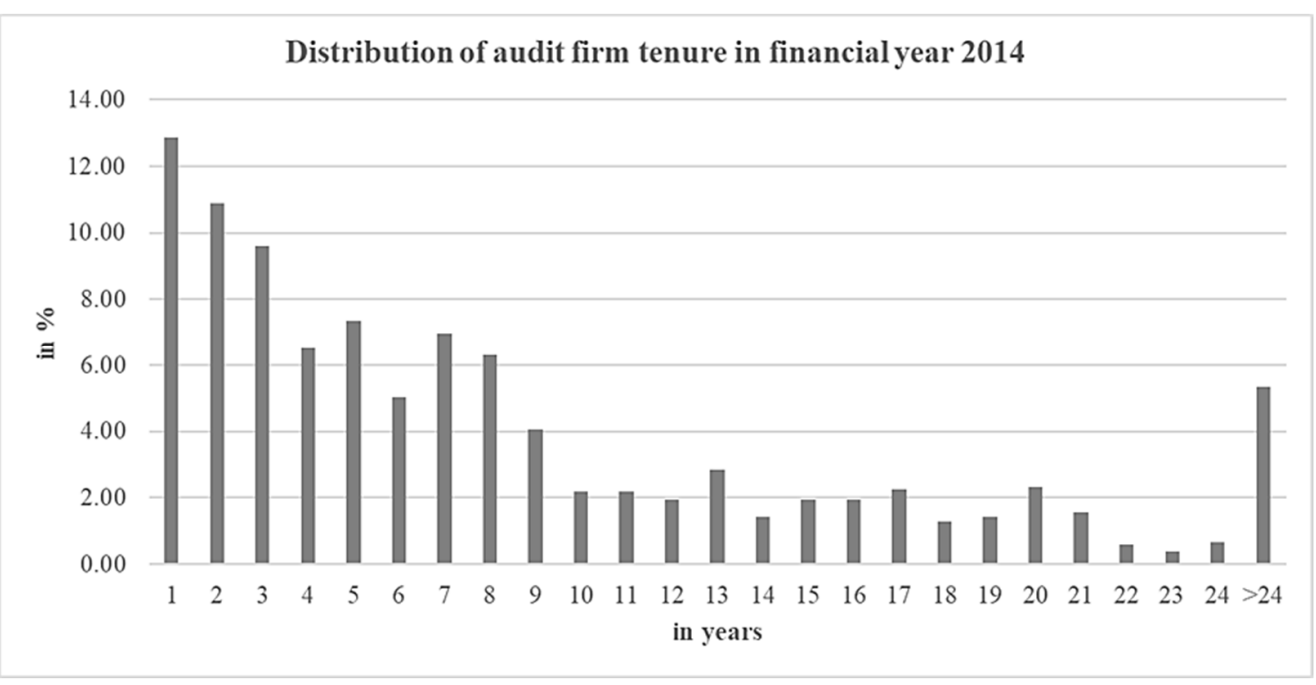

Figure 2. Distribution of audit firm tenure.

\subsubsection{An individual Analysis on Member State Level}

As stated above the respective member states decided to introduce different maximum durations. We therefore performed an individual analysis on member state level to split the results. To answer RQ 2, we follow a two-step procedure. First, we investigated the respective average audit firm tenure per member state, considering the wide range of standard-deviation. We then compared the respective introduced maximum duration with the percentage of entities effected by the political decisions at that time. To do so, we determined the proportion of audit firm tenure longer than the respective maximum duration as introduced in the member state in the financial year 2014.

In total 384 of the entities within our data set were affected by the introduced maximum durations, nearly 30\% (see Table 5). Apart from three member states (Slovenia, Italy, and Iceland) the regulation shows overall effects, which means that the analyzed listed companies from that country were affected. These effects vary from $8.33 \%$ to $57.14 \%$ depending on the distribution and average of audit firm tenure and the respective maximum duration introduced.

In contrast to the aggregated distribution within the whole EU which is shown on the left (see Figure 3), there are some member states that differ from this distribution. At first, Denmark has a nearly U-Curve distribution, which explains that more than 50\% of the entities were affected by the established maximum duration of 10 years in that country. Furthermore, in some countries the figures are nearly equally distributed (such as Belgium, Cyprus, Czech Republic, Estonia, Hungary, and Latvia). For example, we would like to point out the distribution in Ireland, which is shown on the right side (see Appendix ATable A1). 
Table 5. Comparison of maximum durations with average audit firm tenure and proportion of affected companies.

\begin{tabular}{cccccc}
\hline Member State & $\begin{array}{c}\text { Maximum Duration before } \\
\text { Extending Options }\end{array}$ & $\mathbf{n}$ & $\begin{array}{c}\text { Average } \\
\text { Tenure }\end{array}$ & $\begin{array}{c}\text { Affected } \\
\text { Companies }\end{array}$ & \% \\
\hline Austria & 10 & 15 & 8.53 & 4 & 26.67 \\
Belgium & 9 & 37 & 11.46 & 18 & 48.65 \\
Bulgaria & 7 & 12 & 5.33 & 3 & 25.00 \\
Croatia & 10 & 8 & 4.50 & 1 & 12.50 \\
Cyprus & 10 & 20 & 14.90 & 10 & 50.00 \\
Czech Rep. & 10 & 5 & 8.50 & 2 & 50.00 \\
Denmark & 10 & 91 & 12.35 & 49 & 53.85 \\
Estonia & 10 & 16 & 9.00 & 4 & 25.00 \\
Finland & 10 & 104 & 10.66 & 36 & 34.62 \\
France & 6 & 0 & $\mathrm{~N} / \mathrm{A}$ & $\mathrm{N} / \mathrm{A}$ & $\mathrm{N} / \mathrm{A}$ \\
Germany & 10 & 223 & 10.72 & 75 & 33.63 \\
Greece & 10 & 34 & 7.62 & 9 & 26.47 \\
Hungary & 10 & 7 & 12.43 & 4 & 57.14 \\
Iceland & 10 & 1 & 2.00 & 0 & 0.00 \\
Ireland & 10 & 18 & 13.78 & 8 & 44.44 \\
Italy & 9 & 180 & 4.96 & 0 & 0.00 \\
Latvia & 10 & 17 & 5.24 & 3 & 17.65 \\
Lithuania & 10 & 8 & 8.43 & 3 & 42.86 \\
Luxemburg & 10 & 15 & 7.53 & 3 & 20.00 \\
Malta & 10 & 0 & $\mathrm{~N} / \mathrm{A}$ & $\mathrm{N} / \mathrm{A}$ & $\mathrm{N} / \mathrm{A}$ \\
Netherlands & 10 & 78 & 8.33 & 25 & 32.05 \\
Poland & 5 & 104 & 3.72 & 11 & 18.64 \\
Portugal & 10 & 22 & 7.95 & 8 & 36.36 \\
Romania & 10 & 5.92 & 1 & 8.33 \\
Slovakia & 10 & 6.00 & 1 & 20.00 \\
Slovenia & 10 & 2.55 & 0 & 0.00 \\
Spain & 10.33 & 21 & 34.43 \\
Sweden & 10 & 9.33 & 85 & 37.44 \\
\hline & 10 & & & \\
\hline
\end{tabular}

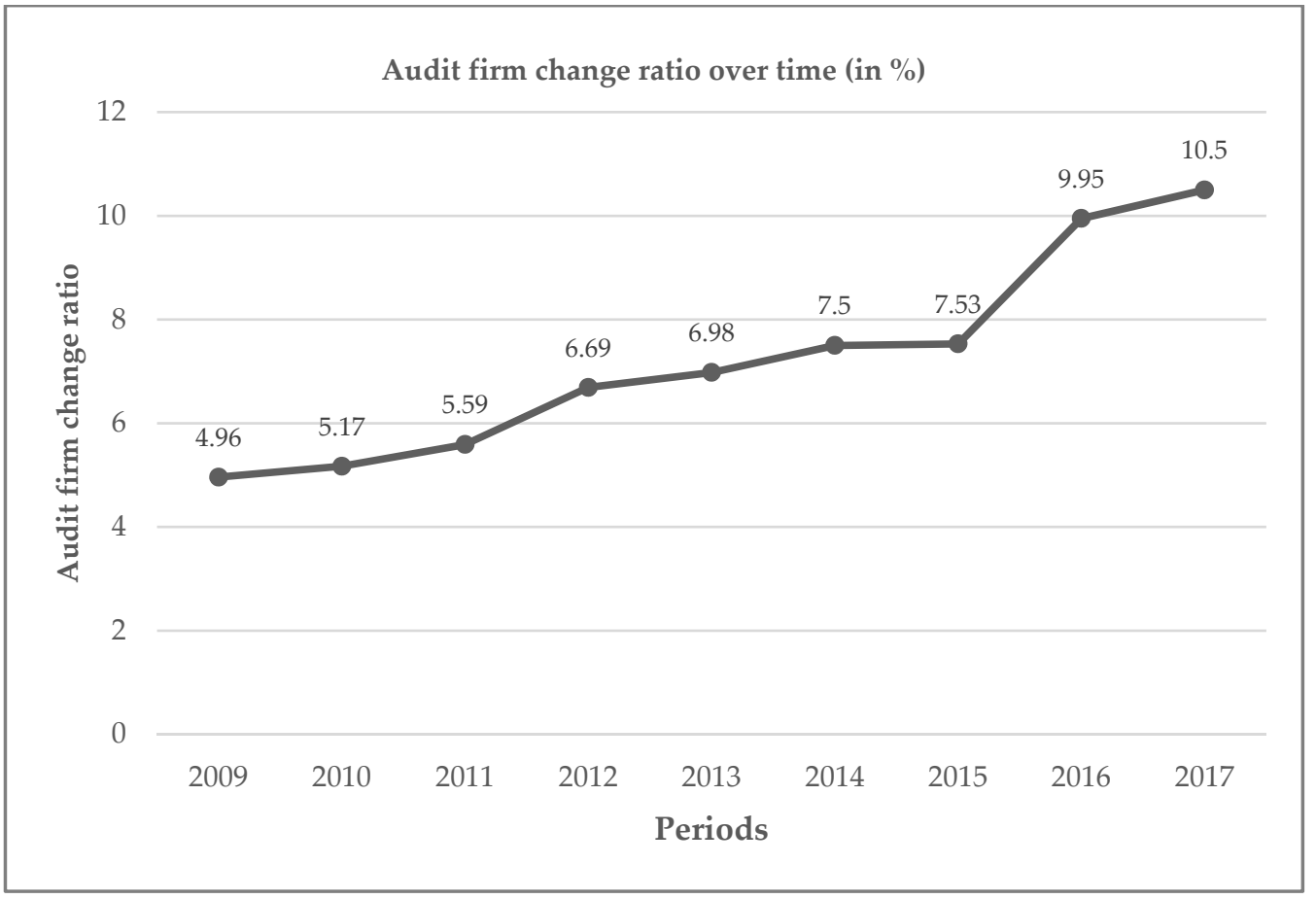

Figure 3. Audit firm change ratio over time. 


\subsubsection{Further Reflections on the Empirical Results}

The decrease in average audit firm tenure after Regulation (EU) No. 537/2014 agreed to in 2014 is remarkable, due to the fact that the regulation was not effective at that date. However, after a long period of discussion about the introduction, there was now clarity for the companies and auditors concerned. Increased changes of audit firms at that time can thus be seen as a kind of anticipatory obedience to a future obligationpossibly also connected with the fear of not being able to obtain the future partner of choice. The fact that there were no effects on average audit firm tenure prior to the adoption of Regulation 537/2014 does not seem surprising, not least because a possible introduction has already been discussed several times but-apart from individual member states-was not introduced in the end.

Furthermore, we noticed an increase in the auditor change ratio per year. Given the number of 10 years as a maximum duration, the respective change ratio that would explicitly result is $10 \%$. As we can see for the periods 2016 and 2017 (i.e., when Regulation EU 537/2014 came into effect), the change ratio per year increased compared to all previous years. Even if the necessity of a rotation-related change of auditors has not yet arisen for individual companies, the increase in the change ratio could be also explained as a kind of anticipatory obedience.

However, it is rather premature to conclude that the established maximum duration of ten years will continue to stimulate market conditions within the EU. At this point in time, it is not yet clear whether the implemented extension options will actually be used.

The list of the individual member states shows that the trends of audit firm tenure diverge within the EU since Regulation EU No. 537/2014 was agreed to. While the increase in average audit firm tenures seems unbroken in 15 Member States ( $\uparrow$ ), there are 11 Member States whose average audit firm tenures are actually continuously decreasing over time $(\downarrow)$. As per 31 December 2017, the lowest average audit firm tenure is from Ireland at 3.20 years whereas the highest average audit firm tenure is from Cyprus at 16.45 years (see Table 6).

Table 6. Audit firm tenure over time on member state level.

\begin{tabular}{|c|c|c|c|c|c|c|}
\hline Member State & $\begin{array}{l}\text { Maximum Duration } \\
\text { Including Extensions }\end{array}$ & 2014 & 2015 & 2016 & 2017 & Trend \\
\hline Austria & 10 & 8.53 & 8.41 & 8.05 & 7.95 & \\
\hline Belgium & 24 & 11.46 & 11.10 & 10.58 & 10.41 & \\
\hline Bulgaria & 7 & 5.33 & 5.57 & 5.13 & 3.36 & \\
\hline Croatia & 24 & 4.50 & 4.60 & 5.60 & 5.15 & \\
\hline Cyprus & 24 & 14.90 & 15.19 & 16.19 & 16.45 & \\
\hline Czech Republic & 20 & 7.60 & 7.33 & 8.33 & 9.33 & \\
\hline Denmark & 20 & 12.35 & 12.69 & 13.61 & 13.60 & \\
\hline Estonia & 20 & 9.00 & 10.00 & 11.00 & 11.81 & \\
\hline Finland & 24 & 10.66 & 11.06 & 11.39 & 11.87 & \\
\hline France & 20 & $\mathrm{~N} / \mathrm{A}$ & $\mathrm{N} / \mathrm{A}$ & $\mathrm{N} / \mathrm{A}$ & $\mathrm{N} / \mathrm{A}$ & \\
\hline Germany & 24 & 10.30 & 10.73 & 11.46 & 11.37 & \\
\hline Greece & 10 & 7.62 & 7.56 & 8.41 & 8.18 & \\
\hline Hungary & 10 & 12.43 & 13.43 & 11.88 & 9.64 & \\
\hline Iceland & 20 & 2.00 & 1.50 & 2.20 & 3.20 & \\
\hline Ireland & 10 & 13.78 & 12.81 & 11.00 & 10.82 & $\checkmark$ \\
\hline Italy & 9 & 4.91 & 4.73 & 4.54 & 4.35 & 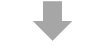 \\
\hline
\end{tabular}


Table 6. Cont.

\begin{tabular}{ccccccc}
\hline Member State & $\begin{array}{c}\text { Maximum Duration } \\
\text { Including Extensions }\end{array}$ & $\mathbf{2 0 1 4}$ & $\mathbf{2 0 1 5}$ & $\mathbf{2 0 1 6}$ & $\mathbf{2 0 1 7}$ & Trend \\
\hline Latvia & 20 & 8.43 & 6.60 & 6.27 & 5.36 & $\checkmark$ \\
Lithuania & 10 & 5.24 & 6.24 & 7.12 & 6.57 & \\
Luxemburg & 20 & 7.53 & 8.53 & 9.53 & 9.41 & \\
Malta & 20 & $\mathrm{~N} / \mathrm{A}$ & $\mathrm{N} / \mathrm{A}$ & $\mathrm{N} / \mathrm{A}$ & $\mathrm{N} / \mathrm{A}$ & \\
Netherlands & 10 & 8.33 & 5.42 & 3.05 & 3.42 & \\
Poland & 5 & 3.72 & 3.87 & 3.76 & 3.88 & \\
Portugal & 9 & 7.95 & 8.29 & 8.60 & 6.63 & \\
Romania & 20 & 5.92 & 5.73 & 4.76 & 5.14 & \\
Slovakia & 24 & 6.00 & 7.00 & 8.00 & 9.00 & \\
Slovenia & 20 & 2.55 & 3.55 & 4.00 & 4.67 & \\
Spain & 14 & 9.33 & 9.22 & 9.25 & 8.66 & \\
Sweden & 24 & 9.33 & 9.39 & 9.79 & 10.14 & \\
\hline
\end{tabular}

Finally, as an answer to RQ 2, we see different effects on the member states based on the respective maximum durations in the member states.

\section{Discussion from the Perspective of Public Choice}

Taking the agreed maximum duration of 10 years before mandatory audit firm rotation into consideration, we want to look back at the origins of the regulation. Prior to the final regulation the respective European institutions all made their own proposals regarding a potential maximum duration of audit engagements. With respect to the organizational structure of the EU, we identify three institutions that determine political decisions within the union, and therefore, the legal regulation of the European audit market. By assuming the EU as a collective that must decide based on the preferences of the three institutions, the EU Commission, EU Parliament, and EU Council of Ministers, we provide a possible explanation based on the Public Choice framework for collective decision-making by Buchanan and Tullock (1962) (further, as an overview and application, Follert et al. 2020, esp. 5-13). Within the Buchanan and Tullock model, collective decision-making is modeled as a consensus. The different institutions (members) that are involved in a decision-making process tend to have different interests and the rules of a process can help to reduce this conflict. Divergent interests seem to be evident also for the different institutions within the $\mathrm{EU}$, in particular regarding the different member states and the different interests between governments (here Council of Ministers) and population(s) (here Parliament) (Downs 1957). Therefore, we would like to discuss the maximum duration within the EU regulation as a result of a consent between three institutions with particular interests that is shown graphically in Figure 4.

Perspective of the EU Commission

The EU Commission presented a proposal for a reform package based on a directive and a regulation on 30 November 2011. This proposal provided for a mandatory maximum duration of 6 years. However, an extension option up to nine years was suggested, provided that the audit would be carried out jointly by two audit firms. (Art. 33 of the proposal for a Directive by EU Commission 2011).

At that time (2011), and considering the proposed maximum duration of 6 years, all member states except Italy, Croatia, Luxemburg, Poland, Romania, Slovakia, and Slovenia would have been affected by the rotation requirement. Apart from the last-mentioned member states, all others had average auditor tenures of more than six years. 


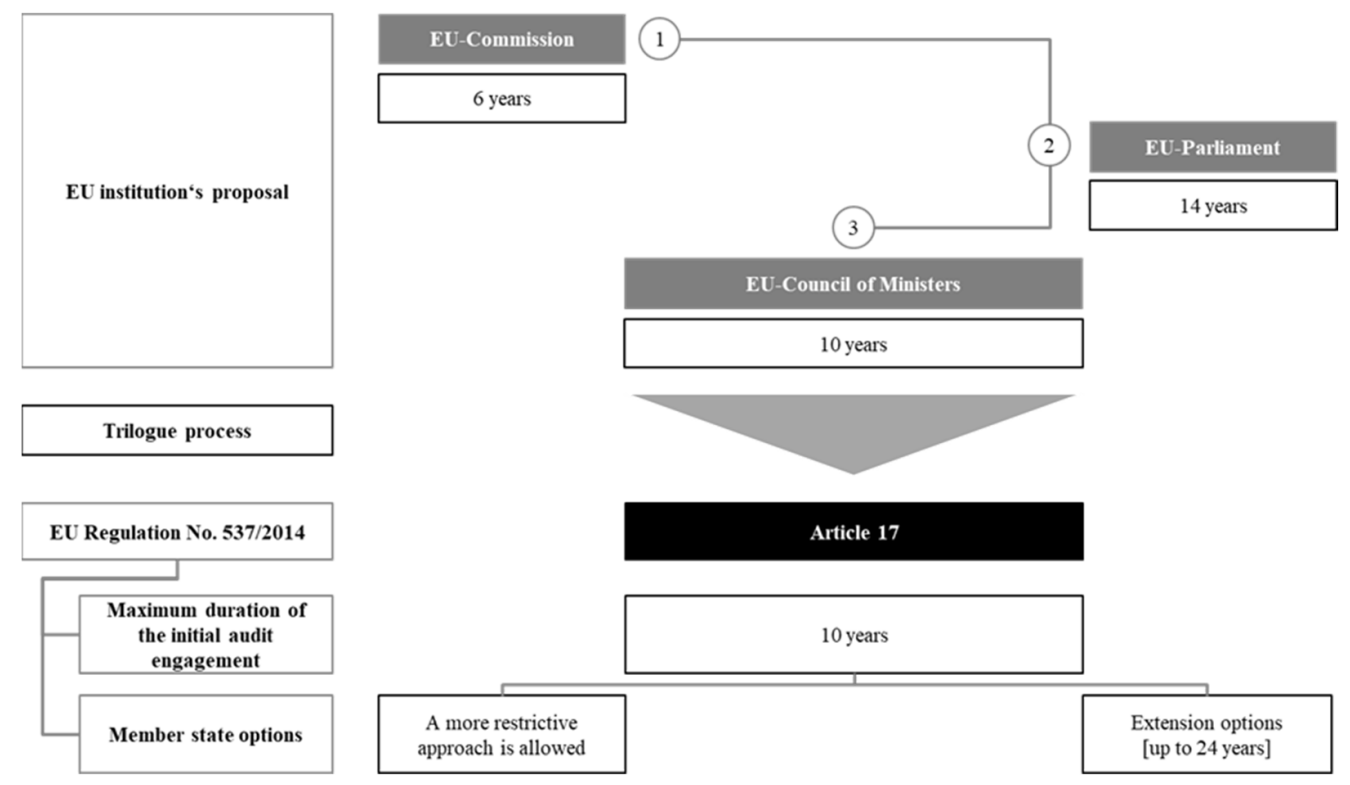

Figure 4. The "ten year" consent process by EU politicians.

\section{Perspective of the EU Parliament}

The European Parliament responded with its own proposal considering a maximum duration of 14 years for audit engagements and after rounds of negotiations about the maximum duration that should be established (see Naumann and Herkendell 2013, as the original document is no longer available).

At that time (2013), and considering the proposed maximum duration of 14 years, there was no member state that would have been affected on average by that rotation requirement, since all had average auditor tenures of less than fourteen years.

Perspective of EU Council of Ministers

In addition to this, the EU Council of Ministers followed through on the reforms by suggesting 10 years as a maximum period. Therefore, an informal trialogue process had to be convened between the European Parliament and the EU Council of Ministers, where the EU Commission played the role as a mediator to find a consensus (see Naumann and Herkendell 2013, as the original document is no longer available).

Given the agreed duration of 10 years as stated in Article 17 of EU Regulation No. $537 / 2014$, it seems more than doubtful that this value was chosen based on empirical evidence. Regarding the maximum duration of 6 years, as proposed by the EU Commission, the head of the audit unit in the Directorate General of the Internal Market and Services of the European Commission made the following statement to the PCAOB while in attendance at a public meeting about auditor independence and audit firm rotation in the US, as of 18 October 2012 (see PCAOB 2012):

"We have proposed six years in case of solo audits and nine years in case of joint audits. We see some proposing maybe ten years, and of course, we will see what the final outcome will be".

Therefore, it seems not unlikely that the final duration is the outcome of a political consensus between the proposal of the EU Commission and the EU Parliament following the simple equation:

$$
\text { Maximum duration in years }=\frac{\left[6_{\text {as proposed by EU-Commission }}+14_{\text {as proposed by EU-Parliament }]}\right.}{2}=10
$$

However, it cannot be ruled out that the individual proposals of the respective EU institutions may have been influenced, at least in part, by the interests of various lobby groups. From a classical liberal perspective, regulation could only make economic sense if 
the marginal costs of the market intervention correspond to the marginal utility. From a Public Choice perspective, this is still questionable at this point, since it is assumed that politicians try to maximize their votes to stay in office and to consume the amenities of being in charge (Downs 1957; with application to accounting, May and Sundem 1976; Tinker 1980; Cooper and Sherer 1984; Sutton 1984; Ordelheide 1998; Homfeldt 2013). Most of the work, however, focuses on the lobbying approach (with application to business valuation, e.g., Quill 2016; Follert 2020). However, this approach does not apply to the issue under consideration. A possible explanatory approach could therefore be the self-interest axiom of political actors, which is operationalized by maximizing votes (Schumpeter 1950; Downs 1957). The Downsian approach can be used to analyze political action within the sphere of classical management decisions, e.g., the composition of boards (Olbrich et al. 2016). In this respect, it is conceivable that the measures were also used to appease taxpayers after various crises.

\section{Concluding Remarks and Outlook}

It would be wise to limit audit tenure to 10 years if there were evidence that this is the period where audit quality reaches its maximum, i.e., that any longer audit mandate would (on average) result in audit opinions of poorer reliability. This is clearly not the case.

No matter how audit quality is defined in detail, it is out of the question that independence is one of-if not the-core element(s). Apparently, European audit regulators focus on the argument that auditors' independence suffers from longer audit tenure-at least in public perception. In case of corporate failure where the auditor (a) was provided with a clean audit opinion and (b) was in charge for a long period, the only available explanation seems to be the impaired independence of the instance that stands for unbiased opinions and extensive expertise- the auditor. The public does (and regulators do?) not see that a $95 \%$ accuracy of audit opinion (which is the quality level required by audit standards) implicitly means that - on average-one in twenty audits fails to find all material misstatements. This phenomenon, which is well-known as the expectation gap, is immanent to standard audit procedures no matter if audit tenure is capped or not.

The fact that there is no clear evidence-neither formal nor empirical-that audit quality suffers from long audit tenures tells us that there is also no evidence that auditors' independence in fact is corrupted by long audit tenure. From this perspective, there is no need to cap audit tenure at all-i.e., the 10-year cap is not "proven".

Instead, EU regulators started a process to improve the public perception of the reliability of the audit outcomes, the so-called 'independence in appearance'. They installed a maximum audit tenure of 10 years, which seems to be the result of a political process initiated by media pressure on the political authorities; however, this was apparently rather an effort at 'pretend' political action than installing a well-founded effective measure. In that respect, the 10-year limit is "public", not "proven". Moreover, due to the decentralized nature of knowledge (Hayek 1945) and the difficulty of forecasting future events from past data, the question arises whether such a hard number can be considered useful at all, or rather whether the discovery of the optimal mandate duration is not a task for the market process (Hayek 1969).

The aim of the present study is to emphasize that the political intervention within the European audit market is at least partially driven by other reasons than empirical evidence. This seems astonishing, as the COVID-19 crisis particularly reveals the importance of evidence-based policy. Since we could at least find indications that the 10-year period is not based on the scientific findings of international audit research, we discuss our findings in the light of Public Choice Theory and thus contribute to the New Political Economy of audit market regulation. One possible explanation could be that the choice of the 10-year period is the result of a collective decision and can be understood as a consensus between the EU institutions.

However, the informative value of our study could be limited because we have not analyzed data from certain industries and the data collection was performed manually 
based on the annual reports as presented on the websites of the respective companies. This results in a very low degree of coverage for some member states (e.g., $<10 \%$ of the population in Czech Republic, Slovakia, and Malta), which may distort the results and should be considered in the interpretation of our findings. It is undisputed that further research is needed to make a valid judgement on the effectiveness of the regulatory measures as a whole.

While our paper provides primary and only descriptive evidence on the setting of maximum durations, to be able to make a final economic assessment of the actual effects of market intervention, further research, especially statistical analyses, e.g., based on regression analyses, are needed, in particular regarding the appropriateness of the measures and the political influence (e.g., Masud et al. 2019). Possible proxies for appropriateness could possibly be the measurement of audit quality and the perception of audit quality before and after regulation came into effect. Another approach could be to analyze whether the different maximum durations correlate with the individual company law of the Member State. Overall future research should build on our interdisciplinary approach between economics, politics, and law.

With our findings concerning the need for regulation of auditor tenure, we contribute to the discussion on the regulation of important sectors and the economic rationality of those political decisions, as well as the link between political decisions and empirical evidence.

This study discussed publicly available audit firm tenure data for listed companies within the European Union. The results indicate that when Regulation (EU) No. 537/2014 was agreed to in 2014 and came into effect in 2016, the average durations of audit engagements were in both cases lower than the established maximum duration for future periods.

Author Contributions: Conceptualization, M.W. (Markus Widmann), F.F., and M.W. (Matthias Wolz); methodology, M.W. (Matthias Wolz) and F.F.; data curation, M.W. (Markus Widmann); writingoriginal draft preparation, M.W. (Markus Widmann) and F.F.—review and editing, M.W. (Matthias Wolz); visualization, M.W. (Markus Widmann) and F.F.; supervision, M.W. (Matthias Wolz); project administration, F.F. All authors have read and agreed to the published version of the manuscript.

Funding: This research received no external funding.

Institutional Review Board Statement: Not applicable.

Informed Consent Statement: Not applicable.

Data Availability Statement: We hand collected publicly available data from financial statements.

Acknowledgments: We would like to thank three anonymous referees and the academic editor for their valuable comments. In particular, we thank Reviewer 1 for providing further material on the evaluation of the EU audit reform. Their suggestions helped us to improve the paper.

Conflicts of Interest: The authors declare no conflict of interest. 


\section{Appendix A}

Table A1. Distribution of audit firm tenure in financial year, 2014.

\begin{tabular}{|c|c|c|c|c|c|c|c|c|c|c|c|c|c|c|c|c|c|c|c|c|c|c|c|c|c|c|}
\hline Tenure & AUT & BE & BG & CY & $\mathrm{CZ}$ & $\mathrm{DE}$ & DK & $\mathrm{EE}$ & ES & FI & GR & HR & $\mathrm{HU}$ & IE & IS & IT & LT & LU & $\mathbf{L V}$ & NL & PL & PT & RO & $\mathrm{SE}$ & SL & SK \\
\hline 1 & 0.00 & 0.05 & 0.25 & 0.00 & 0.25 & 0.08 & 0.14 & 0.06 & 0.11 & 0.12 & 0.15 & 0.13 & 0.00 & 0.06 & 0.00 & 0.08 & 0.47 & 0.07 & 0.14 & 0.28 & 0.29 & 0.18 & 0.17 & 0.09 & 0.18 & 0.00 \\
\hline 2 & 0.27 & 0.05 & 0.08 & 0.00 & 0.00 & 0.11 & 0.08 & 0.00 & 0.18 & 0.10 & 0.03 & 0.13 & 0.00 & 0.11 & 1.00 & 0.12 & 0.06 & 0.07 & 0.00 & 0.04 & 0.19 & 0.05 & 0.08 & 0.12 & 0.27 & 0.20 \\
\hline 3 & 0.00 & 0.03 & 0.25 & 0.15 & 0.25 & 0.08 & 0.07 & 0.06 & 0.10 & 0.07 & 0.09 & 0.13 & 0.00 & 0.00 & 0.00 & 0.19 & 0.06 & 0.07 & 0.14 & 0.04 & 0.12 & 0.00 & 0.08 & 0.09 & 0.45 & 0.20 \\
\hline 5 & 0.00 & 0.08 & 0.00 & 0.05 & 0.00 & 0.09 & 0.03 & 0.00 & 0.02 & 0.10 & 0.15 & 0.13 & 0.14 & 0.06 & 0.00 & 0.13 & 0.00 & 0.07 & 0.14 & 0.03 & 0.08 & 0.14 & 0.00 & 0.04 & 0.09 & 0.00 \\
\hline 6 & 0.00 & 0.08 & 0.00 & 0.00 & 0.00 & 0.08 & 0.04 & 0.06 & 0.03 & 0.01 & 0.03 & 0.13 & 0.14 & 0.06 & 0.00 & 0.04 & 0.12 & 0.00 & 0.14 & 0.09 & 0.07 & 0.00 & 0.17 & 0.02 & 0.00 & 0.40 \\
\hline 7 & 0.00 & 0.08 & 0.00 & 0.25 & 0.00 & 0.03 & 0.01 & 0.13 & 0.08 & 0.11 & 0.06 & 0.00 & 0.00 & 0.06 & 0.00 & 0.11 & 0.00 & 0.33 & 0.00 & 0.06 & 0.03 & 0.05 & 0.08 & 0.10 & 0.00 & 0.00 \\
\hline 8 & 0.20 & 0.11 & 0.00 & 0.00 & 0.00 & 0.07 & 0.02 & 0.13 & 0.00 & 0.07 & 0.09 & 0.00 & 0.00 & 0.11 & 0.00 & 0.12 & 0.06 & 0.13 & 0.00 & 0.04 & 0.02 & 0.05 & 0.08 & 0.06 & 0.00 & 0.00 \\
\hline 9 & 0.00 & 0.03 & 0.00 & 0.00 & 0.00 & 0.04 & 0.00 & 0.13 & 0.03 & 0.04 & 0.06 & 0.00 & 0.00 & 0.06 & 0.00 & 0.12 & 0.00 & 0.00 & 0.00 & 0.04 & 0.02 & 0.09 & 0.00 & 0.03 & 0.00 & 0.00 \\
\hline 10 & 0.07 & 0.03 & 0.00 & 0.00 & 0.00 & 0.03 & 0.00 & 0.06 & 0.02 & 0.02 & 0.00 & 0.00 & 0.00 & 0.00 & 0.00 & 0.01 & 0.00 & 0.00 & 0.00 & 0.03 & 0.02 & 0.09 & 0.17 & 0.03 & 0.00 & 0.00 \\
\hline 11 & 0.00 & 0.03 & 0.00 & 0.00 & 0.00 & 0.02 & 0.01 & 0.00 & 0.00 & 0.03 & 0.06 & 0.13 & 0.00 & 0.00 & 0.00 & 0.00 & 0.00 & 0.00 & 0.14 & 0.06 & 0.00 & 0.05 & 0.00 & 0.04 & 0.00 & 0.00 \\
\hline 12 & 0.00 & 0.00 & 0.08 & 0.00 & 0.00 & 0.01 & 0.00 & 0.00 & 0.02 & 0.02 & 0.03 & 0.00 & 0.00 & 0.00 & 0.00 & 0.00 & 0.06 & 0.00 & 0.00 & 0.09 & 0.02 & 0.09 & 0.00 & 0.04 & 0.00 & 0.00 \\
\hline 13 & 0.00 & 0.00 & 0.08 & 0.00 & 0.25 & 0.04 & 0.01 & 0.00 & 0.08 & 0.03 & 0.00 & 0.00 & 0.29 & 0.06 & 0.00 & 0.00 & 0.00 & 0.13 & 0.00 & 0.03 & 0.00 & 0.09 & 0.08 & 0.02 & 0.00 & 0.20 \\
\hline 14 & 0.00 & 0.08 & 0.00 & 0.00 & 0.00 & 0.03 & 0.01 & 0.00 & 0.00 & 0.03 & 0.00 & 0.00 & 0.00 & 0.00 & 0.00 & 0.00 & 0.00 & 0.00 & 0.00 & 0.01 & 0.00 & 0.00 & 0.00 & 0.02 & 0.00 & 0.00 \\
\hline 15 & 0.00 & 0.05 & 0.00 & 0.05 & 0.00 & 0.01 & 0.04 & 0.06 & 0.02 & 0.01 & 0.00 & 0.00 & 0.00 & 0.00 & 0.00 & 0.00 & 0.00 & 0.00 & 0.14 & 0.00 & 0.00 & 0.00 & 0.00 & 0.05 & 0.00 & 0.00 \\
\hline 16 & 0.07 & 0.00 & 0.00 & 0.10 & 0.00 & 0.03 & 0.03 & 0.00 & 0.03 & 0.05 & 0.03 & 0.00 & 0.00 & 0.00 & 0.00 & 0.00 & 0.00 & 0.00 & 0.00 & 0.00 & 0.00 & 0.00 & 0.00 & 0.02 & 0.00 & 0.00 \\
\hline 17 & 0.00 & 0.08 & 0.08 & 0.05 & 0.25 & 0.04 & 0.03 & 0.13 & 0.00 & 0.01 & 0.06 & 0.00 & 0.00 & 0.00 & 0.00 & 0.00 & 0.00 & 0.00 & 0.00 & 0.00 & 0.00 & 0.00 & 0.00 & 0.03 & 0.00 & 0.00 \\
\hline 18 & 0.00 & 0.08 & 0.00 & 0.00 & 0.00 & 0.01 & 0.02 & 0.00 & 0.00 & 0.00 & 0.00 & 0.00 & 0.00 & 0.06 & 0.00 & 0.00 & 0.00 & 0.00 & 0.14 & 0.03 & 0.00 & 0.00 & 0.00 & 0.03 & 0.00 & 0.00 \\
\hline 19 & 0.13 & 0.00 & 0.00 & 0.05 & 0.00 & 0.02 & 0.03 & 0.06 & 0.00 & 0.01 & 0.06 & 0.00 & 0.00 & 0.00 & 0.00 & 0.00 & 0.06 & 0.00 & 0.00 & 0.01 & 0.02 & 0.00 & 0.00 & 0.00 & 0.00 & 0.00 \\
\hline 21 & 0.00 & 0.00 & 0.00 & 0.00 & 0.00 & 0.00 & 0.02 & 0.00 & 0.00 & 0.01 & 0.00 & 0.00 & 0.00 & 0.00 & 0.00 & 0.00 & 0.06 & 0.07 & 0.00 & 0.01 & 0.00 & 0.00 & 0.00 & 0.07 & 0.00 & 0.00 \\
\hline 22 & 0.00 & 0.03 & 0.00 & 0.00 & 0.00 & 0.00 & 0.00 & 0.00 & 0.00 & 0.00 & 0.03 & 0.00 & 0.14 & 0.00 & 0.00 & 0.00 & 0.00 & 0.00 & 0.00 & 0.00 & 0.00 & 0.00 & 0.00 & 0.02 & 0.00 & 0.00 \\
\hline 23 & 0.00 & 0.03 & 0.00 & 0.00 & 0.00 & 0.00 & 0.01 & 0.00 & 0.00 & 0.01 & 0.00 & 0.00 & 0.00 & 0.00 & 0.00 & 0.00 & 0.00 & 0.00 & 0.00 & 0.00 & 0.00 & 0.00 & 0.00 & 0.00 & 0.00 & 0.00 \\
\hline 24 & 0.00 & 0.00 & 0.00 & 0.00 & 0.00 & 0.01 & 0.00 & 0.00 & 0.07 & 0.00 & 0.00 & 0.00 & 0.14 & 0.00 & 0.00 & 0.00 & 0.00 & 0.00 & 0.00 & 0.03 & 0.00 & 0.00 & 0.00 & 0.00 & 0.00 & 0.00 \\
\hline \multirow[t]{2}{*}{$>24$} & 0.00 & 0.08 & 0.00 & 0.20 & 0.00 & 0.09 & 0.11 & 0.00 & 0.10 & 0.12 & 0.00 & 0.00 & 0.00 & 0.33 & 0.00 & 0.00 & 0.00 & 0.00 & 0.00 & 0.05 & 0.00 & 0.05 & 0.00 & 0.02 & 0.00 & 0.00 \\
\hline & 1.00 & 1.00 & 1.00 & 1.00 & 1.00 & 1.00 & 1.00 & 1.00 & 1.00 & 1.00 & 1.00 & 1.00 & 1.00 & 1.00 & 0.00 & 1.00 & 1.00 & 1.00 & 1.00 & 1.00 & 1.00 & 1.00 & 1.00 & 1.00 & 1.00 & 1.00 \\
\hline
\end{tabular}




\section{References}

Accountancy Europe. 2017. Definition of Public Interest Entities in Europe-State of Play after the Implementation of the 2014 Audit Reform. Available online: https://www.accountancyeurope.eu/wp-content/uploads/171130-Publication-Definition-of-PublicInterest-Entities-in-Europe_1.pdf (accessed on 7 September 2020).

Accountancy Europe. 2020. Implementation of the 2014 EU Audit Directive and Regulation in 30 European Countries. Available online: https://www.accountancyeurope.eu/wp-content/uploads/Audit-policy-implementation-state-of-play_July-2020-1-1 .pdf (accessed on 10 February 2021).

Al-Thuneibat, Ali A., Ream T. I. Al Issa, and Rana A. Baker. 2011. Do audit tenure and firm size contribute to audit quality? Managerial Auditing Journal 26: 317-34. [CrossRef]

Audit Analytics. 2020. Monitoring the Audit Market in Europe. December. Sutton: Audit Analytics.

Baatwah, Saeed Rabea. 2016. Audit tenure and financial reporting in Oman: Does rotation affect the quality. Risk Governance and Control: Financial Markets \& Institutions 6: 16-27.

Bagus, Philipp. 2011. The Tragedy of the Euro. Eastbourne: Terra Libertas.

Bagus, Philipp. 2013. Mises' Staats- und Interventionismuskritik. Edited by Polleit Thorsten. München: FBV, pp. 89-109.

Bagus, Philipp. 2015. The ZIRP Trap-The Institutionalization of Negative Real Interest Rates. Procesos de Mercado: Revista Europea de Economía Política 12: 105-63.

Baiman, Stanley. 1979. Discussion of Auditing: Incentives and Truthful Reporting. Journal of Accounting and Economics Supplement 17: 25-29. [CrossRef]

Barth, James R., Tong Li, and Wenling Lu. 2010. Bank Regulation in the Unites States. CESifo Economic Studies 56: 112-40. [CrossRef]

Berle, Adolf A., and Gardiner C. Means. 1968. The Modern Corporation and Private Property. New York: Harcourt, Brace.

Bigus, Jochen, and Ruth-Caroline Zimmermann. 2008. Non-Audit Fees, Market Leaders and Concentration in the German Audit Market: A Descriptive Analysis. International Journal of Auditing 12: 159-79. [CrossRef]

Biondi, Yuri. 2011. The pure logic of accounting: A critique of the fair value revolution. Accounting, Economics, and Law 1: 1-46. [CrossRef]

Böcking, Hans-Joachim, Marius Gros, Christoph Wallek, and Daniel Worret. 2011. Das Grünbuch, “Weiteres Vorgehen im Bereich der Abschlussprüfung: Lehren aus der Krise": Ergebnisse der Konsultation. Die Wirtschaftsprüfung 64: 1159-70.

Boone, Jeff P., Inder K. Khurana, and K. K. Raman. 2008. Audit firm tenure and the equity risk premium. Journal of Accounting, Auditing and Finance 23: 115-40. [CrossRef]

Braun, Eduard. 2019. The Ecological Rationality of Historical Costs and Conservatism. Accounting, Economics, and Law 9: 1-30. [CrossRef]

Brooks, Li (Lily) Z., C. S. Agnes Cheng, Joseph A. Johnston, and Kenneth J. Reichelt. 2017. Estimate of Optimal Audit Firm Tenure Across Different Legal Regimes. Journal of Accounting, Auditing E Finance 32: 3-39.

Brösel, Gerrit, Martin Toll, and Mario Zimmermann. 2012. Lessons learned from the financial crisis—Unveiling alternative approaches within valuation and accounting theory. Financial Reporting 4: 87-107. [CrossRef]

Buchanan, James M., and Gordon Tullock. 1962. The Calculus of Consent. Logical Foundations of Constitutional Democracy. Ann Arbor: University of Michigan Press.

Carcello, Joseph V., and Albert L. Nagy. 2004. Audit Firm Tenure and Fraudulent Financial Reporting. Auditing: A Journal of Practice E Theory 23: 55-69.

Carey, Peter, and Roger Simnett. 2006. Audit Partner Tenure and Audit Quality. The Accounting Review 81: 653-76. [CrossRef]

Chen, Chih-Ying, Chan-Jane Lin, and Yu-Chen Lin. 2008. Audit Partner Tenure, Audit Firm Tenure, and Discretionary Accruals: Does Long Auditor Tenure Impair Earnings Quality. Contemporary Accounting Research 25: 415-45. [CrossRef]

Chung, Dennis Y., and Daryl Lindsay. 1988. The pricing of audit services: The Canadian perspective. Contemporary Accounting Research 5: 19-46. [CrossRef]

Coates, John C. V. 2007. The Goals and Promises of the Sarbanes-Oxley Act. Journal of Economic Perspectives 21: 91-116. [CrossRef]

Cooper, David J., and Michael J. Sherer. 1984. The Value of Corporate Accounting Reports: Arguments for a Political Economy of Accounting. Accounting, Organization and Society 9: 207-32. [CrossRef]

Daniels, Bobbie W., and Quinton Booker. 2011. The effects of audit firm rotation on perceived auditor independence and audit quality. Research in Accounting Regulation 23: 78-82. [CrossRef]

Davies, Paul. 2015. The Fall and Rise of Debt: Bank Capital Regulation After the Crisis. European Business Organization Law Review 16: 491-512. [CrossRef]

Davis, Larry R., Billy S. Soo, and Gregory M. Trompeter. 2009. Auditor Tenure and the Ability to Meet or Beat Earnings Forecasts. Contemporary Accounting Research 26: 517-48. [CrossRef]

DeAngelo, Linda E. 1981. Auditor Independence, 'Low Balling', And Disclosure Regulation. Journal of Accounting and Economics 3: 113-27. [CrossRef]

Downs, Anthony. 1957. An Economic Theory of Democracy. New York: Harper.

Emrich, Eike, and Florian Follert. 2019. Totgesagte leben länger! Einige Anmerkungen zum homo oeconomicus als Methode. Wirtschaftspolitische Blätter 66: 337-47.

Ettredge, Michael, Matthew G. Sherwood, and Lili Sun. 2018. Effects of SOX 404(b) implementation on audit fees by SEC filer size category. Journal of Accounting and Public Policy 37: 21-38. [CrossRef] 
European Commission. 2010. Green Paper. Audit Policy: Lessons from the Crisis. Available online: https://eur-lex.europa.eu/legalcontent/EN/TXT/HTML/?uri=CELEX:52010DC0561\&from=DE (accessed on 9 October 2020).

Evans, Lisa, and Kersten Honold. 2007. The division of expert labour in the European audit market: The case of Germany. Critical Perspectives on Accounting 18: 61-88. [CrossRef]

Ewert, Ralf. 1990. Wirtschaftsprüfung und Asymmetrische Information. Berlin/Heidelberg: Springer.

Follert, Florian, Lukas Richau, Eike Emrich, and Christian Pierdzioch. 2020. Collective Decision-Making: FIFA from the Perspective of Public Choice. The Economist's Voice 17: 20190031. [CrossRef]

Follert, Florian. 2020. Zur Unternehmensbewertung im Spruchverfahren aus interessentheoretischer Sicht. Der aktienrechtliche Minderheitenausschluss im Lichte der Neuen Politischen Ökonomie. Wiesbaden: Springer Gabler.

Ghosh, Aloke, and Doocheol Moon. 2005. Auditor Tenure and Perceptions of Audit Quality. The Accounting Review 80: 585-612. [CrossRef]

Hayek, Friedrich A. Von. 1945. The Use of Knowledge in Society. The American Economic Review 35: 519-30.

Hayek, Friedrich A. Von. 1969. Der Wettbewerb als Entdeckungsverfahren. In Freiburger Studien. Edited by Friedrich A. von Hayek. Tübingen: Mohr, pp. 249-65.

Hering, Thomas, Michael Olbrich, and Roland Rollberg. 2010. Zur angelsächsischen Bewertungstheorie als Mitursache der Finanzkrise. In Corporate Governance, Risk Management und Compliance. Edited by Frank Keuper Fritz Neumann. Wiesbaden: Gabler, pp. 29-43.

Herzig, Norbert, and Christoph Watrin. 1995. Obligatorische Rotation des Wirtschaftsprüfers-Ein Weg zur Verbesserung der externen Unternehmenskontrolle? Schmalenbachs Zeitschrift für Betriebswirtschaftliche Forschung 47: 775-804.

Holmström, Bengt. 1979. Moral hazard and observability. The Bell Journal of Economics 10: 74-91. [CrossRef]

Homfeldt, Niklas Benedict. 2013. Interessengeleitete Rechnungslegung. Wiesbaden: Springer Gabler.

Hossain, Sarowar. 2013. Effect of Regulatory Changes on Auditor Independence and Audit Quality. International Journal of Auditing 17: 246-64. [CrossRef]

Huerta de Soto, Jesus. 2009. Financial Crisis: The Failure of Accounting Reform. Mises Daily Articles 02/04/2009. Available online: https:/ / mises.org/library / financial-crisis-failure-accounting-reform (accessed on 2 May 2021).

Humphrey, Christopher, Asad Kausar, Anne Loft, and Margaret Woods. 2011. Regulating Audit beyond the Crisis: A Critical Discussion of the EU Green Paper. European Accounting Review 20: 431-57. [CrossRef]

Jackson, Andrew B., Michael Moldrich, and Peter Roebuck. 2008. Mandatory audit firm rotation and audit quality. Managerial Auditing Journal 23: 420-37. [CrossRef]

Jensen, Michael C., and William H. Meckling. 1976. Theory of the firm: Managerial behavior, agency costs and ownership structure. Journal of Financial Economics 3: 305-60. [CrossRef]

Johnson, Van E., Inder K. Khurana, and J. Kenneth Reynolds. 2002. Audit-Firm Tenure and the Quality of Financial Reports. Contemporary Accounting Research 19: 637-60. [CrossRef]

Kaserer, Christoph. 2010. Regulierung und Aufsicht der Banken: Brauchen wir Basel III? ifo Schnelldienst 63: 14-17.

Kim, Moo Sung, Jagadish Dandu, and Perihan Iren. 2019. The effect of SOX on audit quality. Journal of Financial Crime 26: 897-909. [CrossRef]

Kirchgässner, Gebhard. 2013. Homo Oeconomicus, 4th ed. Tübingen: Mohr Siebeck.

Knechel, W. Robert, and Ann Vanstraelen. 2007. The relationship between auditor tenure and audit quality implied by going concern opinions. Auditing: A Journal of Practice \& Theory 26: 113-31.

Kurrild-Klitgaard, Peter. 2005. The Political Economy of the Dynamic Nature of Government Intervention: An Introduction to Potentials and Problems. In The Dynamics of Intervention: Regulation and Redistribution in the Mixed Economy. Edited by Kurrild-Klitgaard Peter. (Advances in Austrian Economics 8). Bingley: Emerald Group Publishing Limited, pp. 3-20.

Kwon, Soo Young, Youngdeok Lim, and Roger Simnett. 2014. The Effect of Mandatory Audit Firm Rotation on Audit Quality and Audit Fees: Empirical Evidence from the Korean Audit Market. Auditing: A Journal of Practice and Theory 33: 167-95. [CrossRef]

Lim, Chee Yeow, and Hun-Tong Tan. 2010. Does Auditor Tenure Improve Audit Quality? Moderating Effects of Industry Specialization and Fee Dependence. Contemporary Accounting Research 27: 923-57. [CrossRef]

Marten, Kai-Uwe. 1994. Empirische Analyse des Prüferwechsels im Kontext der Agency- und Signalling-Theorie. Zeitschrift für Betriebswirtschaft 65: 703-27.

Masud, Md, Abdul Kaium, Seong M. Bae, Javier Manzanares, and Jong D. Kim. 2019. Board Director's Expertise and Corporate Corruption Disclosure: The Moderating Role of Political Connections. Sustainability 11: 4491. [CrossRef]

May, Robert G., and Gary L. Sundem. 1976. Research for Accounting Policy: An Overview. The Accounting Review 51: 747-63.

McKenzie, Richard B., and Gordon Tullock. 1978. The New World of Economics, 2nd ed. Homewood: Irwin.

Mises, Ludwig Von. 1926. Interventionismus. Archiv für Sozialwissenschaft und Sozialpolitik 56: 610-53.

Mises, Ludwig Von. 1957. Die Wahrheit über den Interventionismus. Monatsblätter für Freiheitliche Wirtschaftspolitik 3: $599-607$.

Mises, Ludwig Von. 1998. Interventionism: An Economic Analysis. New York: The Foundation for Economic Education.

Myers, James N., Linda A. Myers, and Thomas C. Omer. 2003. Exploring the Term of the Auditor-Client Relationship and the Quality of Earnings: A Case for Mandatory Auditor Rotation? The Accounting Review 78: 779-99. [CrossRef]

Naumann, Klaus-Peter. 2014. Die Regulierung der Abschlussprüfung in Europa. In Rechnungslegung, Prüfung und Unternehmensbewertung: Festschrift für Wolfgang Ballwieser. Edited by Michael Dobler, Dirk Hachmeister, Christoph Kuhner and Stefan Rammert. Stuttgart: Schäffer-Poeschel, pp. 521-46. 
Naumann, Klaus-Peter, and Anja Herkendell. 2013. Regulierung der Abschlussprüfung_Aktueller Stand der Diskussion in Brüssel. Die Wirtschaftsprüfung 66: 1181-85.

Neurohr, Jonas, Florian Follert, and Marc Schild. 2019. Chancen und Herausforderungen kleiner und mittlerer Gesellschaften im deutschen Wirtschaftsprüfungsmarkt_Eine empirische Analyse. Die Unternehmung-Swiss Journal of Business Research and Practice 73: 250-75.

Olbrich, Michael, Anna E. Nikolis, David J. Rapp, and Katrin V. Weber. 2016. Do Political Parties Play Dirty in the Discussion on Gender Balanced Boards? Evidence from Germany. Schmalenbach Business Review 17: 361-99. [CrossRef]

Opp, Karl-Dieter. 1999. Contending Conceptions of the Theory of Rational Action. Journal of Theoretical Politics 11: 171-202. [CrossRef]

Ordelheide, Dieter. 1998. Zur Politischen Ökonomie der Rechnungslegung. Schmalenbachs Zeitschrift für betriebswirtschaftliche Forschung 40: 1-16.

Public Company Accounting Oversight Board. 2012. Auditor Independence and Audit Firm Rotation PCAOB Rulemaking Docket Matter No. 37. Available online: https:/ / pcaobus.org/Rulemaking/Docket037/2012-10-18_Transcript_Houston.pdf (accessed on 20 September 2020).

Pratt, John W., and Richard J. Zeckhauser. 1985. Principals and Agents: An Overview. In Principals and Agents: The Structure of Business. Edited by John Winsor Pratt and Richard J. Zeckhauser. Boston: Harvard Business School Press, pp. 1-35.

Quick, Reiner, and Daniela Wiemann. 2011. Zum Einfluss der Mandatsdauer des Abschlussprüfers auf die Prüfungsqualität. Zeitschrift für Betriebswirtschaft 81: 915-43. [CrossRef]

Quill, Tobias. 2016. Interessengeleitete Unternehmensbewertung. Wiesbaden: Springer Gabler.

Reguera-Alvarado, Nuria, Pilar de Fuentes, and Joaquina Laffarga. 2019. Do auditors mitigate earnings management during economic crisis? Revista de Contabilidad Spanish Accounting Review 22: 6-20.

Ross, Stephen A. 1973. The Economic Theory of Agency: The Principal's Problem. The American Economic Review 63: 134-39.

Rudolph, Bernd. 2010. Die internationale Finanzkrise als Anstoß für Weiterentwicklungen im Risikocontrolling der Banken und für Reformen in der Bankregulierung. Schmalenbachs Zeitschrift für Betriebswirtschaftliche Forschung 62: 122-49. [CrossRef]

Schumpeter, J. A. 1950. Capitalism, Socialism, and Democracy. New York: Harper \& Brothers Publishers.

Simon, Danie T., and Jere R. Francis. 1988. The Effects of Auditor Change on Audit Fees: Tests of Price Cutting and Price Recovery. The Accounting Review 63: 255-69.

Sutton, Timothy G. 1984. Lobbying of Accounting Standard-Setting Bodies in the UK and the U.S.A.: A Downsian Analysis. Accounting, Organization and Society 9: 81-95. [CrossRef]

Tan, Boon Seng, and Yew Kee Ho. 2016. Some Economics of Audit Market Reform. Australian Accounting Review 26: 271-83. [CrossRef]

Tanyi, Paul, and Barrit Litt. 2017. The Unintended Consequences of the Frequency of PCAOB Inspection. Journal of Business Finance $\mathcal{E}$ Accounting 44: 116-53.

Tinker, Anthony M. 1980. Towards a Political Economy of Accounting: An Empirical Illustration of the Cambridge Controversies. Accounting, Organization and Society 5: 147-60. [CrossRef]

Velte, Patrick, and Markus Stiglbauer. 2012. Audit Market Concentration and Its Influence on Audit Quality. International Business Research 5: 146-61. [CrossRef]

Widmann, Markus, and Matthias Wolz. 2019. Prüfungsqualität im Spannungsfeld von Joint Audits und externer Rotation—Lassen die unterschiedlichen Umsetzungsmaßnahmen der EU-Mitgliedstaaten zukünftig tatsächlich qualitativ hochwertigere Abschlussprüfungen erwarten? Zeitschrift für Corporate Governance 14: 222-29.

Widmann, Markus, and Matthias Wolz. 2020. Die Laufzeit des Prüfungsverhältnisses im EU-Vergleich—Erfüllen die Umsetzungen der Nationalstaaten zur externen Pflichtrotation des Abschlussprüfers ihren Zweck? WP Praxis 9: 136-40.

Widmann, Markus, Florian Follert, and Matthias Wolz. 2021. What is it going to cost? Empirical evidence from a systematic literature review of audit fee determinants. Management Review Quarterly 71: 455-89. [CrossRef]

Willekens, Marleen, Simon Dekeyser, and Ines Simac. 2019. EU Statutory Audit Reform-Impact on Costs, Concentration and Competition. Available online: https:/ / www.europarl.europa.eu/RegData/etudes/STUD/2019/631057/IPOL_STU(2019)631 057_EN.pdf (accessed on 22 October 2020).

Wolz, Matthias. 2004. Die Festlegung von Wesentlichkeitsgrenzen in der deutschen Wirtschaftsprüfungspraxis. Schmalenbachs Zeitschrift für betriebswirtschaftliche Forschung 56: 122-45. [CrossRef]

Zeit Online. 2020. Olaf Scholz Will Finanzaufsicht Reformieren. Available online: https://www.zeit.de/wirtschaft/unternehmen/20 20-07/olaf-scholz-plant-umbau-finanzaufsicht-nach-bilanzskandal-wirecard (accessed on 8 September 2020). 